\title{
CHRONOLOGICAL FRAMEWORK OF THE SIBERIAN PALEOLITHIC: RECENT ACHIEVEMENTS AND FUTURE DIRECTIONS
}

\author{
Yaroslav V Kuzmin \\ Pacific Institute of Geography, Far Eastern Branch of the Russian Academy of Sciences, Radio St. 7, Vladivostok 690041, \\ Russia. Email: ykuzmin@tig.dvo.ru.
}

\begin{abstract}
In Siberia, the accumulation of radiocarbon dates from archaeological sites since the 1960s makes it possible to compile a general Paleolithic ${ }^{14} \mathrm{C}$ database, which contains about 440 entries as of late 2005 . With these data, we can reveal the main chronological patterns of Paleolithic complexes, with a focus on the late Middle Paleolithic (Mousterian) and Upper Paleolithic. The ${ }^{14} \mathrm{C}$ dates for late Middle Paleolithic industries in Siberia are quite "young," up to about 30,000-28,500 BP and perhaps $\sim 27,000$ BP. The emergence of the Upper Paleolithic in Siberia took place relatively early compared with Eastern Europe. At about 43,000-35,000 BP, blade-dominated industries existed in the Altai Mountains and Lake Baikal region, and numerous adornments are known from several sites of that age. The late Upper Paleolithic complexes with microblade technology from the Altai Mountains are ${ }^{14} \mathrm{C}$ dated to about $35,000-28,000 \mathrm{BP}$, and represent the earliest unequivocal evidence of microblade manufacture in northern Eurasia. The end of the Paleolithic in Siberia is related to the appearance of pottery, which indicates the beginning of the Neolithic period. In northern Transbaikal, the earliest pottery complexes are dated to about 12,000-11,000 BP and in the Russian Far East even to $\sim 13,000$ BP, while in most of Siberia they date to approximately 8000-6000 BP. The most important features of the Siberian Paleolithic chronology are: a) the long persistence of Middle Paleolithic complexes, until about 30,000-27,000 BP; b) very early Middle to Upper Paleolithic transition, 43,000 BP, closely connected with the emergence of art and symbolic behavior in the earliest Upper Paleolithic at this time; c) the very early origin of microblade complexes, at least at about 35,000 BP; and d) a gradual Paleolithic-Neolithic transition, beginning in the Russian Far East at $\sim 13,000 \mathrm{BP}$ and in Transbaikal about 12,000-11,000 BP, in most of Siberia at about $8000-6000 \mathrm{BP}$, and even later in some northern regions.
\end{abstract}

\section{INTRODUCTION}

A reliable archaeological chronology can only be constructed on the basis of radiometric dating methods. The compilation of a general chronological framework is important for all further refinements of regional archaeological chronologies. In the vast area of Siberia and the Russian Far East, covering approximately $13,000,000 \mathrm{~km}^{2}$ (Figure 1), the accumulation of ${ }^{14} \mathrm{C}$ dates from Paleolithic cultural complexes began in the 1960s. Comprehensive lists of ${ }^{14} \mathrm{C}$ dates with general archaeological descriptions for the main subdivisions of the Siberian Paleolithic have been published in the last $10 \mathrm{yr}$ or so (Kuzmin and Orlova 1998; Goebel and Slobodin 1999; Vasil'ev et al. 2002). With these data in hand, it is now possible to consider the main chronological patterns of the Paleolithic complexes in Siberia.

\section{MATERIALS AND METHODS}

To study and summarize the Paleolithic chronology of Siberia, the major method used is radiocarbon dating. About 130 sites belonging to the late Middle Paleolithic (i.e. Mousterian) and the Upper Paleolithic have been ${ }^{14} \mathrm{C}$ dated (Figure 1), and summaries published before 2006 (Vasil'ev et al. 2002; with additions in Kuzmin and Keates 2005:778-9). In total, about $440{ }^{14} \mathrm{C}$ dates are available from these sites, and they constitute the core of this study.

Other methods have also been employed to establish the age of Lower and Middle Paleolithic sites in Siberia: luminescence dating, including thermoluminescence (TL) and infrared stimulated luminescence (IRSL) methods (e.g. Arkhipov 1999; Waters et al. 1999; Chlachula et al. 2003); radiothermoluminescence (RTL) dating (e.g. Derevianko 2001; Lbova et al. 2003); and electron spin resonance (ESR; in some papers "EPR") dating (e.g. Derevianko et al. 1993). However, uncertainties related to the basic concepts of 2 approaches, namely the RTL method developed by Vlasov and 


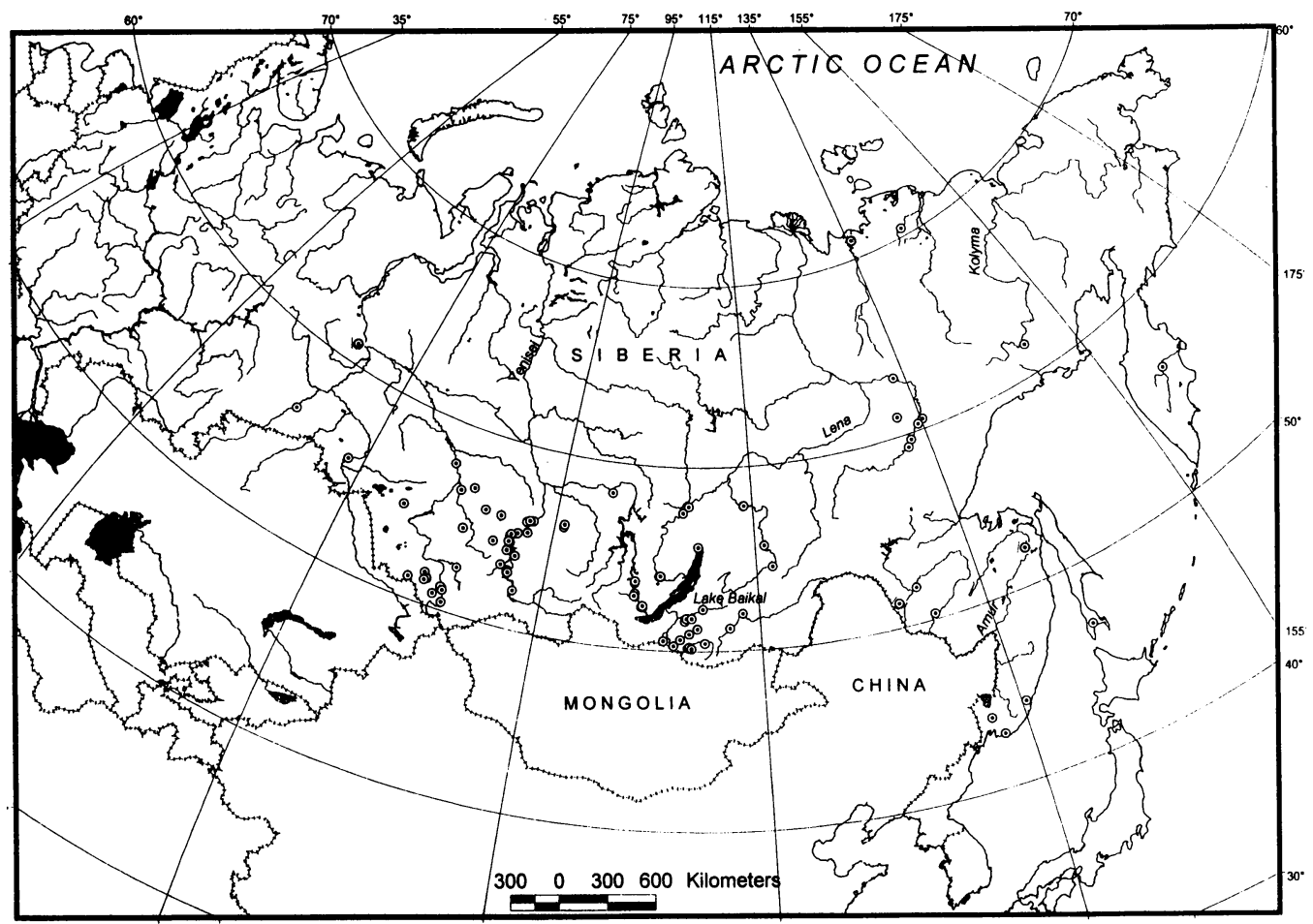

Figure $1{ }^{14} \mathrm{C}$-dated Siberian Paleolithic sites used in this study

Kulikov (1989) (see Huntley 1992; Kuzmin 2000a:35-7) and the ESR method employed by Astashkin et al. (1993) (see Kuzmin 2000a), do not allow us to accept most of the age determinations produced by these techniques at face value.

There are 2 major types of Upper Paleolithic assemblages in Siberia: the macroblade complex with a dominance of blade tools and cores (early Upper Paleolithic), and the microblade complex with wedge-shaped cores and microblades detached from them (late and final Upper Paleolithic) (see review in Kuzmin and Orlova 1998). ${ }^{14} \mathrm{C}$ dates for each of the 2 complexes were combined and the temporal boundary between them was drawn (Figure 2). This allows us to compile a provisional sketch of regional chronologies for the late Middle Paleolithic and Upper Paleolithic, and for the beginning of the next phase of prehistory, the Neolithic, which is characterized by the presence of pottery (Figure 2). Recent publications on the Paleolithic archaeology of southern Siberia, especially for the Altai Mountains (Derevianko 2001; Derevianko and Rybin 2003; Derevianko and Shunkov 2004; Derevianko et al. 2003) and Transbaikal (Lbova 2002), were taken into account for the characterization of the emergence of Upper Paleolithic complexes, art, and microblade technology.

The accumulation of ${ }^{14} \mathrm{C}$ dates for the Siberian Paleolithic made it possible to begin the modeling of settlement patterns and correlation with climatic changes using the "dates-as-data" approach (sensu Rick 1987; see recent reviews of the method and its application: Gamble et al. 2004, 2005). However, by doing so, caution should be taken when ${ }^{14} \mathrm{C}$ values from the same cultural component are averaged (e.g. Dolukhanov et al. 2002, 2005). The simple averaging, in my opinion, can lead to a significant loss of original information that may be derived from ${ }^{14} \mathrm{C}$ records (see reviews: Kuzmin and Keates 2004, 2005, 2006). Therefore, the development of a consensus methodology of numerical analysis of a ${ }^{14} \mathrm{C}$ date series is an urgent task. 


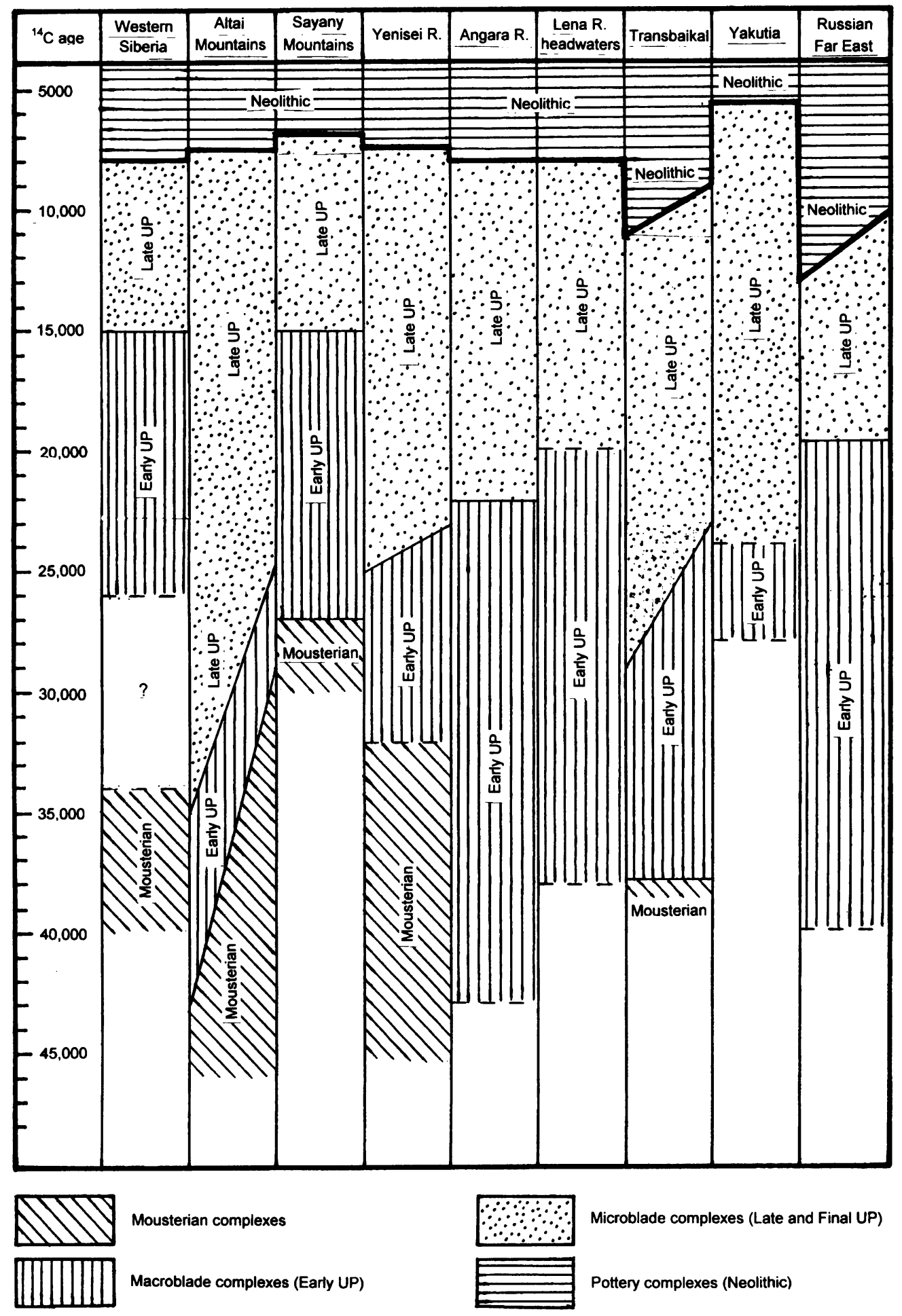

Figure 2 Chronological framework of the Siberian Paleolithic (based on ${ }^{14} \mathrm{C}$ dates and archaeological data) 


\section{RESULTS AND DISCUSSION}

\section{Lower and Early Middle Paleolithic}

There is still no agreement about the radiometric ages of all the Lower Paleolithic complexes and most of the Middle Paleolithic assemblages from Siberia (see review: Kuzmin 2000a). All supposedly Lower Paleolithic sites, including Diring Yuriakh in Yakutia (Mochanov 1993) and Zasukhino in Transbaikal (Lbova et al. 2003), need either additional sampling or confirmation of their age by independent and well-established methods. The RTL method, used for dating several Middle Paleolithic sites-Denisova Cave (layers 22-14), Ust-Karakol 1 (layers 20-18) (Derevianko et al. 2003, 2005), and Khotyk 3 (layers 4-3) (Lbova et al. 2003) - does not appear reliable in terms of its basic principles. This has been shown earlier (Huntley 1992), but a more recent example is that of the Diring Yuriakh site where an RTL date from the layer underneath a cultural-bearing horizon yielded a result in excess of $1,800,000 \mathrm{yr}$ (RTL-454) (Mochanov 1992), while the standard TL method gave an age of 366,000 $\pm 32,000 \mathrm{yr}$ (OTL472) (Waters et al. 1999). All RTL age determinations need to be verified by additional methods before they can be accepted uncritically.

One of the few examples of the successful application of radiometric dating methods to pre-Upper Paleolithic sites in Siberia is the Ust'-Izhul' case (Chlachula et al. 2003). This site, in the upper reaches of the Yenisei River basin, was IRSL dated to $\sim 125,000 \mathrm{yr}$ ago. The ${ }^{14} \mathrm{C}$ dates for Ust'Izhul', obtained on charcoal and bones of the early type of woolly mammoth (Mammuthus primigenius Blum.), are all older than 40,000 BP (Vasil'ev et al. 2002; Chlachula et al. 2003). The TL age of the earlier site of Berezhekovo near Ust'-Izhul' was previously estimated between $~ 540,000 \mathrm{yr}$ ago and 130,000 yr ago (Arkhipov 1999; see also Kuzmin 2000a; Derevianko et al. 2005).

\section{Late Middle Paleolithic}

The typical Middle Paleolithic complexes of southern Siberia may now be dated to at least $\sim 125,000$ yr at the Ust'-Izhul' site (see above). Mousterian-type industries continued to exist in Siberia for a long time. The earliest ${ }^{14} \mathrm{C}$ dates associated with them are in excess of about 42,000-44,000 BP at the Kara-Bom site (e.g. Vasil'ev et al. 2002:521). As was shown before (e.g. Kuzmin 2000a, 2004), the latest Middle Paleolithic assemblages in Siberia are known from the Dvuglazka rockshelter in the upper Yenisei River basin (layers 5-7; Derev'anko and Markin 1998), and the Aryshevskoe 1 site on the West Siberian Plain (Zenin 2002; see also Vasil'ev et al. 2002:521). These sites are dated to about 33,600-27,200 BP (Figures 2-3). The ${ }^{14} \mathrm{C}$ ages of about 26,600-22,500 BP for layer 4 at Dvuglazka (overlying layers 5-7) provide good stratigraphic control. The use of the Dvuglazka rockshelter by hyenas as a den and possible disturbance of the cultural layers means that the ${ }^{14} \mathrm{C}$ value of layer 7 ( 27,200 BP) could be a minimum age (C G Turner II, personal communication, 2004). However, there are several other late Middle Paleolithic sites in Siberia with quite "young" ages, about 30,300-28,500 BP (e.g. Vasil'ev et al. 2002), and the pattern of a long "survival" of the Mousterian technocomplex in Siberia is still evident.

\section{The Emergence of the Upper Paleolithic and Art}

Recent extensive archaeological research of the earliest Upper Paleolithic complexes in southern Siberia with blade-dominated industries, particular in the Altai Mountains and southern Transbaikal (e.g. Derevianko 2001; Lbova 2002), have brought to light information about the timing of its appearance. It is clear now that the earliest Upper Paleolithic assemblages are dated to about 43,300-43,200 BP at the Kara-Bom site (charcoal samples) (Figure 3), and to about 43,900-40,500 $\mathrm{BP}$ at the Podzvonkaya and Kamenka sites (bone samples) (e.g. Orlova et al. 2005). It is obvious that 
the Middle to Upper Paleolithic transition in Siberia was quite a long process (e.g. Kuzmin 2004) rather than a short-term replacement (e.g. Goebel 2002), and both complexes may have coexisted for a long time, from $\sim 43,000 \mathrm{BP}$ to $\sim 27,000 \mathrm{BP}$ (Figure 3).

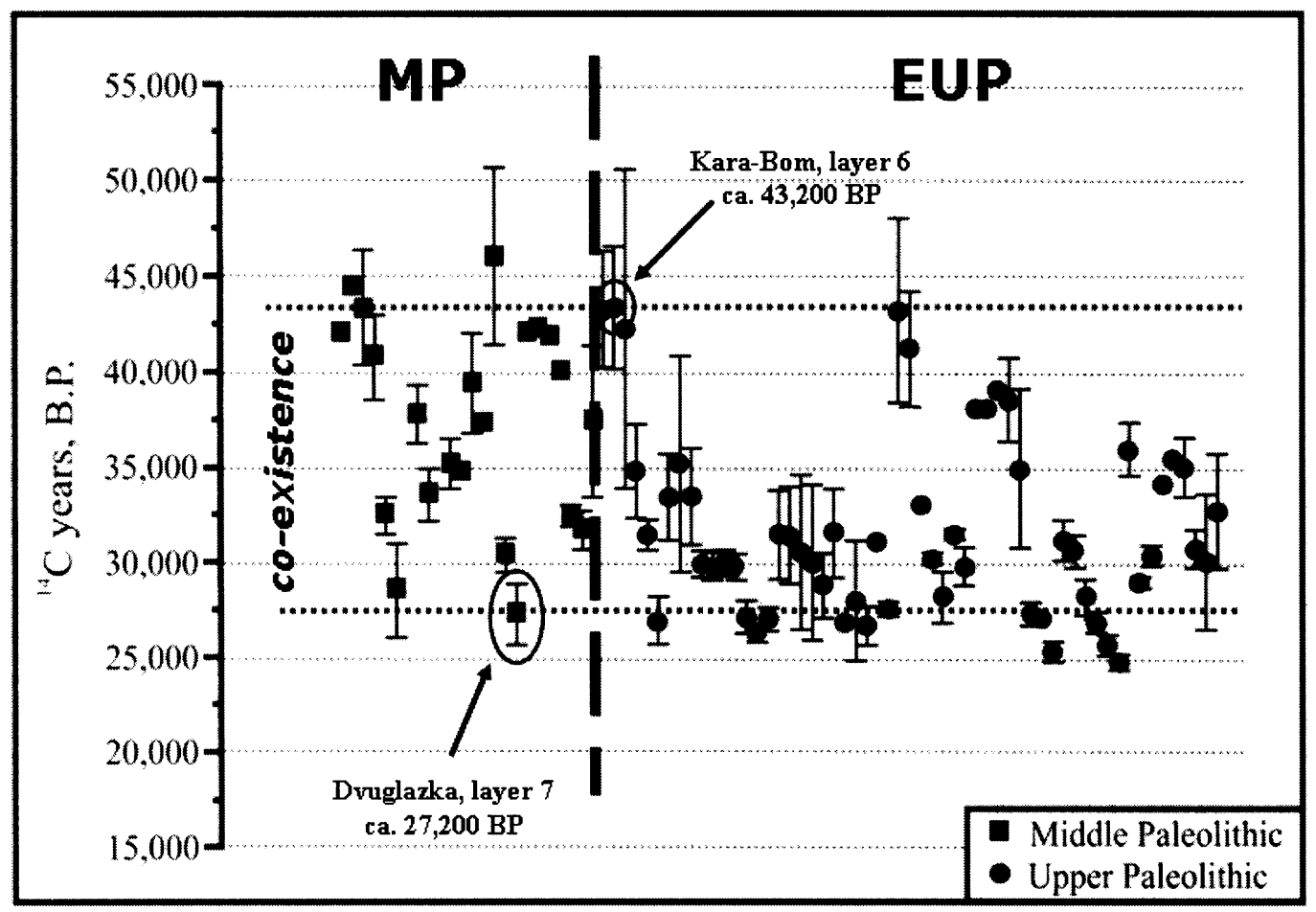

Figure 3 Relationship between the ${ }^{14} \mathrm{C}$ ages of the latest Middle Paleolithic (MP) and earliest Upper Paleolithic (EUP) sites in Siberia (after Kuzmin 2004, with additions).

The elaborate adornments- such as the pendants from the Kara-Bom site directly associated with ${ }^{14} \mathrm{C}$ values of about 43,300-43,200 BP; pendants and beads from the Kamenka and Khotyk sites that may date to about 40,000-26,000 BP (Derevianko and Rybin 2004); and numerous pendants, cylinder beads with ornamentation, and eye needles from the Denisova Cave with an estimated ${ }^{14} \mathrm{C}$ age of at least $\sim 37,000 \mathrm{BP}$ and perhaps older (Derevianko and Shunkov 2004)-strongly testify in favor of a very early appearance of art in southern Siberia, at least at $\sim 43,000$ BP. This is an important discovery for understanding the symbolic behavior in the Upper Paleolithic of Eurasia, and from now on Siberia should be considered as a region with a very early appearance of art and symbolism (e.g. Derevianko et al. 2005).

The very early age of the initial Upper Paleolithic complexes in Siberia poses the problem of their origin in the light of models assuming the emergence of Upper Paleolithic technology and behavior in the Levant and its dissemination toward Europe (e.g. Bar-Yosef 2000), and from Europe to Siberia (e.g. Dolukhanov et al. 2002:603). The fact is that in the East European Plain, the earliest Upper Paleolithic assemblage is from the Kostienki 14 site (the "horizon of hearths") ${ }^{14} \mathrm{C}$ dated to about 37,200-36,300 BP (see latest summaries: Anikovich 2003; Anikovich et al. 2007; Sinitsyn and Hoffecker 2006), significantly younger than the earliest Upper Paleolithic sites in Siberia. 
The ${ }^{14} \mathrm{C}$ date of the earliest Upper Paleolithic industry from the Boker Tachtit site in the Levant is $46,930 \pm 2420$ BP (SMU-259) (e.g. Phillips 1994), i.e. 51,770-42,090 BP (with $\pm 2 \sigma$ ), and this overlaps with the earliest ${ }^{14} \mathrm{C}$ values from the Kara-Bom site in the Altai Mountains, layer 6: 43,200 \pm 1500 BP (GX-17597) (i.e. 46,200-40,200 BP), and layer 5: 43,300 \pm 1600 BP (GX-17596) (i.e. 46,500-40,100 BP) (Goebel et al. 1993; Derevianko and Rybin 2003). These are, in fact, very similar ${ }^{14} \mathrm{C}$ ages, and it is almost impossible to use the Boker Tachtit case as evidence of the Levantine Early Upper Paleolithic as the oldest in Eurasia (e.g. Bar-Yosef 2000). Therefore, the existence of Upper Paleolithic assemblages at several Siberian sites dated to prior $\sim 40,000 \mathrm{BP}$-namely KaraBom, Kara-Tenesh, Kamenka (complex A), and Podzvonkaya (e.g. Derevianko 2001; Lbova 2002) — challenges the view of Siberia as a "backyard" of the Levantine-European Early Upper Paleolithic ecumene, and calls strongly for a revision of existing schemes, e.g. the model proposed by Mellars (2006a,b).

\section{The Beginning of Microblade Technology}

Recent excavations in the Altai Mountains, conducted over the last 10-15 yr, produced evidence of very early microblade complexes (Derevianko 2001, 2005; Derevianko et al. 2003). At the UstKarakol 1 site, microblades and wedge-shaped microblade cores were identified in layers 11 through 9 (Derevianko 2001; Derevianko et al. 2003). While layer 11 has no ${ }^{14} \mathrm{C}$ dates, the overlying layer 10 is dated to $35,100 \pm 2850 \mathrm{BP}$ (SOAN-3259), and layer 9 to about 33,400-29,700 BP (Derevianko et al. 2003). Another site in the Altai, Anui 2, also revealed evidence of microblade technology, dated to about 27,900-26,800 BP (Derevianko et al. 2003, 2005). Therefore, the Altai sites contain the earliest microblades in northern Eurasia, produced from wedge-shaped cores (Derevianko 2005). In southern Transbaikal, the Kamenka site (complex B) has microblades and microcores directly associated with ${ }^{14} \mathrm{C}$ dates of about 28,800-24,600 BP (Lbova 2002).

The appearance of microblade technology in Siberia manifests the beginning of the late Upper Paleolithic substage (Figure 2). It is noteworthy that the early/late Upper Paleolithic boundary varies greatly throughout Siberia, and in some regions such as the West Siberian Plain, typical microblade industries emerged quite late, at $\sim 15,000 \mathrm{BP}$ (e.g. Zenin 2002). Microblade technology in Siberia became widely distributed at about 25,000-20,000 BP (Figure 2). It is clear that the beginning of microblade manufacture in Siberia predates the Last Glacial Maximum (LGM, about 20,000 18,000 BP), contra Goebel $(2002,2004)$, who argues for the post-LGM age of microblade sites in Siberia (see review: Kuzmin and Rybin 2005:44-8).

\section{The Paleolithic-Neolithic Transition and Emergence of Pottery}

The end of the Paleolithic in Siberia coincides with the beginning of pottery manufacture, which in Russian archaeology means the next epoch in prehistory, the Neolithic (see reviews: Kuzmin and Orlova 2000; Kuzmin 2006). Previously, the concept of the Mesolithic, which follows the Paleolithic and precedes the Neolithic, was in use (e.g. Koltsov 1989), but since the 1990s it has been abandoned (e.g. Derev'anko et al. 1998). The earliest pottery is known from the Russian Far East, the Amur River basin, where it is well dated to about 13,300-12,300 BP (Figure 2) (Kuzmin and Orlova 2000; Derevianko et al. 2004; Nesterov et al. 2005; see reviews: Kuzmin 2002, 2006). In northern Transbaikal, at the Ust-Karenga 12 site in the Vitim River basin, the earliest pottery-associated ${ }^{14} \mathrm{C}$ dates are about 12,000-11,000 BP (Kuzmin and Orlova 2000; Vetrov and Kuzmin 2005). Thus, in the Russian Far East and Transbaikal, the end of the Paleolithic is dated to the Late Glacial, about 13,000-11,000 BP. In other regions of Siberia, the Paleolithic-Neolithic transition took place at about 8000-6000 BP (Figure 2). Finally, in some areas of Northeastern Siberia, the beginning of pottery-making is dated to an even later time, about 4500-2500 BP (Kuzmin 2000b). 


\section{CONCLUSIONS}

Based on the results presented here, the main chronological patterns of cultural development in the Siberian Paleolithic may be established. The Middle Paleolithic complexes existed for a long time, since after $\sim 540,000 \mathrm{yr}$ ago and until at least $\sim 30,000 \mathrm{BP}$, and perhaps up to $\sim 27,000 \mathrm{BP}$. The Middle to Upper Paleolithic transition took place in Siberia very early, at least at $\sim 43,000 \mathrm{BP}$, almost simultaneously with the Levant and definitely before the appearance of the Upper Paleolithic in Eastern Europe. The earliest art objects from Siberia are also quite old, about 43,000-40,000 BP, and they appeared concurrently with the Upper Paleolithic complexes. The Paleolithic-Neolithic transition happened progressively, beginning in the Russian Far East at $\sim 13,000 \mathrm{BP}$ and in Transbaikal at about 12,000-11,000 BP, and emerging in the west of Lake Baikal at about 8000-6000 BP.

The coexistence of different prehistoric stages (i.e. late Middle Paleolithic and early Upper Paleolithic, large blade and microblade industries in the Upper Paleolithic, and final Upper Paleolithic and Initial Neolithic complexes) in Siberia is a consistent feature. It seems that prehistoric cultural complexes developed gradually, without sudden replacement, compared with more dynamic cultural changes in Europe.

As for future research in terms of enhancement and refinement of the ${ }^{14} \mathrm{C}$ chronology, much more work needs to be done in the remote northern parts of Siberia. Recent excavations and ${ }^{14} \mathrm{C}$ dating of several sites, including Yana RHS (Pitulko et al. 2004) and Nepa (Goebel 2004), show clearly that people occupied (or at least frequently visited) the central and northern parts of Eastern and Northeastern Siberia at least at about 33,000-27,000 BP. The finds of presumably human-modified mammoth bones at 2 localities in the Siberian Arctic dated to about 33,800-22,400 BP (Duvanny Yar near the Kolyma River mouth and Wrangel Island [see Kuzmin and Orlova 2004:156]), might also testify in favor of very early human penetration to the northernmost latitudes of Eurasia. Thus, the search for pre-LGM sites in Northeastern Siberia is among the most important tasks for the next decade.

The large number of ${ }^{14} \mathrm{C}$ dates available now for the Siberian Paleolithic invites more detailed numerical analysis and, ultimately, the reconstruction of population dynamics and migrations (Kuzmin and Keates 2005), as well as the study of a possible connection between the climatic changes in the last 45,000 yr and the peculiarities of human colonization of Eurasia (Fiedel and Kuzmin, this volume). This kind of research must develop and continue once a consensus is reached on protocols for combining ${ }^{14} \mathrm{C}$ records with wider occupational evidence (see discussion: Kuzmin and Keates 2005:775-7; Gamble et al. 2005:196-7).

\section{ACKNOWLEDGMENTS}

This research was supported by grants from the Russian Foundation for Basic Science (RFFI; nos. 06-06-80108 and 06-06-80258) and US Fulbright Program (nos. 96-21230 and 03-27672). The ${ }^{14} \mathrm{C}$ dating of Siberian Paleolithic sites over the last $15 \mathrm{yr}$ was conducted in collaboration with colleagues from several organizations, including the Institute of Geology and Mineralogy, Siberian Branch of the Russian Academy of Sciences (Novosibirsk), and Geological Institute, Russian Academy of Sciences (Moscow) (both in Russia); Arizona AMS Laboratory, University of Arizona, Tucson, Arizona (USA); Oxford Research Accelerator Unit, Research Laboratory for Archaeology and the History of the Art, Oxford University, Oxford (UK); Centre for Isotope Research, University of Groningen, Groningen (the Netherlands); Inter-University Center for National Science Research facility, Seoul National University, Seoul (Republic of Korea); and Leibniz Laboratory, ChristianAlbrechts University, Kiel (Germany). The ${ }^{14} \mathrm{C}$ dating was supported by grants from RFFI (nos. 96- 
06-80688, 96-05-64837, 99-06-80348, 00-06-80410, 02-06-80282, 03-06-80289, and 03-0564434), US NSF (nos. EAR95-08413, EAR97-30699, and EAR01-15488), and UK Natural Environment Research Council (NERC, no. GR3/12599). I am grateful to Prof C G Turner II (Arizona State University, Tempe, Arizona, USA) for sharing his opinion about the taphonomy of some Siberian Paleolithic sites, and to the anonymous reviewer and proceedings editors for useful suggestions.

\section{REFERENCES}

Anikovich MV. 2003. The early Upper Paleolithic in Eastern Europe. Archaeology, Ethnology and Anthropology of Eurasia 5(2)[no. 14]:15-29.

Anikovich MV, Sinitsyn AA, Hoffecker JF, Holliday VT, Popov VV, Lisitsyn SN, Forman SL, Levkovskaya GM, Pospelova GA, Kuz'mina IE, Burova ND, Goldberg P, Macphail RI, Giaccio B, Praslov ND. 2007. Early Upper Paleolithic in Eastern Europe and implications for the dispersal of modern humans. Science 315(5809):223-6.

Arkhipov SA. 1999. Natural habitat of early man in Siberia. In: Chlachula J, Kemp RA, Tyráček J, editors. Quaternary of Siberia: Quaternary Geology, Palaeontology, and Palaeolithic Archaeology [Sborník Geologichých Věd (Antopozoikum), Český Geologický Ústav, Praha, Special Volume 23]. Prague: Czech Geological Survey. p 133-40.

Astashkin AV, Derevianko AP, Milov AD, Nikolaev SV, Petrin VT, Tsvetkov YD. 1993. EPR dating: the comparison of data about the bone dating on the archaeological site Orkhon 7 (Mongolia) by EPR and ${ }^{14} \mathrm{C}$. $\mathrm{Al}$ taica 3:9-16.

Bar-Yosef O. 2000. The impact of radiocarbon dating on Old World archaeology: past achievements and future expectations. Radiocarbon 42(1):23-39.

Chlachula J, Drozdov NI, Ovodov ND. 2003. Last Interglacial peopling of Siberia: the Middle Palaeolithic site Ust'-Izhul', the upper Yenisei area. Boreas 32(3): 506-20.

Derevianko AP. 2001. The Middle-to-Upper Paleolithic transition in the Altai (Mongolia and Siberia). Archaeology, Ethnology and Anthropology of Eurasia 2(2)[no. 6]:70-103.

Derevianko AP. 2005. Formation of blade industries in Eastern Asia. Archaeology, Ethnology and Anthropology of Eurasia 6(4)[no. 24]:2-29.

Derev'anko A, Markin S. 1998. The Paleolithic of the Altai. In: Derev'anko AP, Shimkin DB, Powers WR, editors. The Paleolithic of Siberia: New Discoveries and Interpretations. Urbana: University of Illinois Press. p 84-106.

Derevianko AP, Rybin EP. 2003. The earliest representations of symbolic behaviour by Paleolithic humans in the Altai Mountains. Archaeology, Ethnology and Anthropology of Eurasia 4(4)[no. 16]:27-50.

Derevianko AP, Shunkov MV. 2004. Formation of the Upper Paleolithic traditions in Altai. Archaeology, Ethnology and Anthropology of Eurasia 5(3)[no. 19]:
$12-40$.

Derevianko AP, Nikolaev SV, Petrin VT. 1993. The dating of the Paleolithic site Kara-Bom with physical methods $\left({ }^{14} \mathrm{C}\right.$ and EPR). Altaica 3:3-8.

Derev'anko AP, Shimkin DB, Powers WR, editors. 1998. The Paleolithic of Siberia: New Discoveries and Interpretations. Urbana: University of Illinois Press. $406 \mathrm{p}$.

Derevianko AP, Shunkov MV, Agadjanian AK, Baryshnikov GF, Malaeva EM, Ulianov VA, Kulik NA, Postnov AV, Anoikin AA. 2003. Prirodnava Sreda $i$ Chelovek v Paleolite Gornogo Altava [Paleoenvironment and Paleolithic Humans of the Mountainous Altai]. Novosibirsk: Izdatelstvo Instituta Arkheologii i Etnografii Sibirskogo Otdeleniya Rossiiskoi Akademii Nauk. 448 p. In Russian and English.

Derevianko AP, Postnov AV, Rybin EP, Kuzmin YV, Keates SG. 2005. The Pleistocene peopling of Siberia: a review of environmental and behavioural aspects. Bulletin of the Indo-Pacific Prehistory Association 25: 57-68.

Derevianko AP, Kuzmin YV, Burr GS, Jull AJT, Kim JC. 2004. AMS ${ }^{14} \mathrm{C}$ age of the earliest pottery from the Russian Far East: 1996-2002 results. Nuclear Instruments and Methods in Physics Research B 223-224: 735-9.

Dolukhanov PM, Shukurov AM, Tarasov PE, Zaitseva GI. 2002. Colonization of northern Eurasia by modern humans: radiocarbon chronology and environment. Journal of Archaeological Science 29(6):593-606.

Dolukhanov PM, Shukurov AM, Tarasov PE, Zaitseva GI. 2005. Reply to Y.V. Kuzmin, S.G. Keates (Journal of Archaeological Science 31 (2004) 141-143). Journal of Archaeological Science 32(7):1125-30.

Fiedel SJ, Kuzmin YV. 2007. Radiocarbon date frequency as an index of intensity of Paleolithic occupation of Siberia: Did humans react predictably to climate oscillations? Radiocarbon, these proceedings.

Gamble C, Davies W, Pettitt P, Richards M. 2004. Climate change and evolving human diversity in Europe during the last glacial. Philosophical Transactions of the Royal Society of London Series B 359(1442):24354.

Gamble C, Davies W, Pettitt P, Hazelwood L, Richards M. 2005. The archaeological and genetic foundations of the European population during the Late Glacial: implications of 'agricultural thinking.' Cambridge Archaeological Journal 15(2):193-223. 
Goebel T. 2002. The Middle to Upper Paleolithic transition in Siberia. Anthropological Papers of the University of Alaska New Series 2(1):94-114.

Goebel T. 2004. The search for a Clovis progenitor in subarctic Siberia. In: Madsen DB, editor. Entering America: Northeast Asia and Beringia Before the Last Glacial Maximum. Salt Lake City: University of Utah Press. p 311-56.

Goebel T, Slobodin SB. 1999. The colonization of Western Beringia: technology, ecology, and adaptations. In: Bonnichsen R, Turnmire KL, editors. Ice Age Peoples of North America: Environments, Origins, and Adaptations of the First Americans. Corvallis: Oregon State University Press. p 104-55.

Goebel T, Derevianko AP, Petrin VT. 1993. Dating the Middle-to-Upper-Paleolithic transition at Kara-Bom. Current Anthropology 34(4):452-8.

Huntley DJ. 1992. Vlasov and Kulikov's method. Ancient TL 10(3):57-8.

Koltsov LV, editor. 1989. Mezolit SSSR [The Mesolithic of the USSR]. Moscow: Nauka. 352 p. In Russian.

Kuzmin YV. 2000a. Geoarchaeology of the Lower, Middle, and Early Upper Palaeolithic of Siberia: a review of current evidence. The Review of Archaeology 21(1): $32-40$.

Kuzmin YV. 2000b. Radiocarbon chronology of the Stone Age cultures on the Pacific coast of Northeastern Siberia. Arctic Anthropology 37(1):120-31.

Kuzmin YV. 2002. The earliest centres of pottery origin in the Russian Far East and Siberia: review of chronology for the oldest Neolithic cultures. Documenta Praehistorica 29:37-46.

Kuzmin YV. 2004. Origin of the Upper Paleolithic in Siberia: a geoarchaeological perspective. In: Brantingham PJ, Kuhn SL, Kerry KW, editors. The Early Upper Paleolithic Beyond Western Europe. Berkeley: University of California Press. p 196-206.

Kuzmin YV. 2006. Chronology of the earliest pottery in East Asia: progress and pitfalls. Antiquity 80(308): 362-71.

Kuzmin YV, Keates SG. 2004. Comment on "Colonization of northern Eurasia by modern humans: radiocarbon chronology and environment" by P.M. Dolukhanov, A.M. Shukurov, P.E. Tarasov and G.I. Zaitseva. Journal of Archaeological Science 29, 593-606 (2002). Journal of Archaeological Science 31(2):1413.

Kuzmin YV, Keates SG. 2005. Dates are not just data: Paleolithic settlement patterns in Siberia derived from radiocarbon records. American Antiquity 70(4):77389.

Kuzmin YV, Keates SG. 2006. Response to "Reply to Y.V. Kuzmin, S.G. Keates (Journal of Archaeological Science 31 (2004) 141-143)" by P.M. Dolukhanov, A.M. Shukurov, P.E. Tarasov, G.I. Zaitseva (Journal of Archaeological Science 32 (2005) 1125-1130). Journal of Archaeological Science 33(6):889-92.
Kuzmin YV, Orlova LA. 1998. Radiocarbon chronology of the Siberian Paleolithic. Journal of World Prehistory 12(1):1-53.

Kuzmin YV, Orlova LA. 2000. The Neolithization of Siberia and the Russian Far East: radiocarbon evidence. Antiquity 74(284):356-65.

Kuzmin YV, Orlova LA. 2004. Radiocarbon chronology and environment of woolly mammoth (Mammuthus primigenius Blum.) in northern Asia: results and perspectives. Earth-Science Reviews 68(1-2):133-69.

Kuzmin YV, Rybin EP. 2005. The Palaeolithic of northeast Asia and Beringia from the Siberian perspective: when quality suffers. The Review of Archaeology 26(1):39-52.

Lbova LV. 2002. The transition from the Middle to Upper Paleolithic in the western Trans-Baikal. Archaeology, Ethnology and Anthropology of Eurasia 3(3)[no. 11]: 59-75.

Lbova LV, Rezanov IN, Kalmykov NP, Kolomiets VL, Dergacheva MI, Fedeneva IN, Vashukevich NV, Volkov PV, Savinova VV, Bazarov BA, Namsaraev DV. 2003. Prirodnaya Sreda i Chelovek v Neopleistotsene (Zapadnoe Zabaikalye i Yugo-Vostochnoe Pribaikalye) [Environment and Humans in the Neopleistocene (Western Transbaikal and South-Eastern CisBaikal)]. Ulan-Ude: Izdatelstvo Buriatskogo Nauchnogo Tsentra Sibirskogo Otdeleniya Rossiiskoi Akademii Nauk. 174 p. In Russian.

Mellars P. 2006a. A new radiocarbon revolution and the dispersal of modern humans in Eurasia. Nature 439(7079):931-5.

Mellars P. 2006b. Going east: new genetic and archaeological perspectives on the modern human colonization of Eurasia. Science 313(5788):796-800.

Mochanov YA. 1992. Drevneishy Paleolit Diringa $i$ Problema Vnetropichskoi Rodiny Chelovechestva [The Ancient Paleolithic Site of Diring and the Problem of a Nontropical Origin for Humankind]. Novosibirsk: Nauka. 254 p. In Russian.

Mochanov YA. 1993. The most ancient Paleolithic of the Diring and the problem of a nontropical origin for humanity. Arctic Anthropology 30(1):22-53.

Nesterov SP, Alkin SV, Petrov VG, Kang CH, Orlova LA, Kuzmin YV, Imamura M, Sakamoto M. 2005. Rezultaty radiouglerodnogo datirovaniya eponimnykh pamyatnikov gromatukhinskoi i novopetrovskoi kultur Zapadnogo Priamurya [Results of radiocarbon dating of eponym sites of the Gromatukha and Novopetrovka cultures in western Amur Basin]. In: Derevianko AP, Molodin VI, editors. Problemy Arkhaeologii, Etnografii, Antropologii Sibiri i Sopredelnykh Territorii. Tom 11. Chast 1. Novosibirsk: Izdatelstvo Instituta Arkheologii i Etnografii Sibirskogo Otdeleniya Rossiiskoi Akademii Nauk. p 168-72. In Russian.

Orlova LA, Kuzmin YV, Lbova LV. 2005. Radiouglerodnye daty pamyatnikov paleolita i mezolita Zabaikalya i Mongolii [Radiocarbon dates of the Paleolithic and 
Mesolithic of the Transbaikal and Mongolia]. In: Lbova LV, editor. Paleoliticheskie Kultury Zabaikalya i Mongolii (Novye Fakty, Metody i Gipotezy). Novosibirsk: Izdatelstvo Instituta Arkheologii i Etnografii Sibirskogo Otdeleniya Rossiiskoi Akademii Nauk. p 88-92. In Russian.

Phillips JL. 1994. The Upper Paleolithic chronology of the Levant and the Nile Valley. In: Bar-Yosef O, Kra RS, editors. Late Quaternary Chronology and Paleoclimates of the Eastern Mediterranean. Tucson: Radiocarbon. p 169-76.

Pitulko VV, Nikolsky PA, Girya EY, Basilyan AE, Tumskoy VE, Koulakov SA, Astakhov SN, Pavlova EY, Anisimov MA. 2004. The Yana RHS site: humans in the Arctic before the Last Glacial Maximum. Science 303(5654):52-6.

Rick JW. 1987. Dates as data: an examination of the Peruvian preceramic radiocarbon record. American Antiquity 52(1):55-73.

Sinitsyn AA, Hoffecker JF. 2006. Radiocarbon dating and chronology of the Early Upper Paleolithic at Kostenki. Quaternary International 152-153:164-74.
Vasil'ev SA, Kuzmin YV, Orlova LA, Dementiev VN. 2002. Radiocarbon-based chronology of the Paleolithic of Siberia and its relevance to the peopling of the New World. Radiocarbon 44(2):503-30.

Vetrov VM, Kuzmin YV. 2005. K istorii izucheniya drevnei keramiki na Verkhnem Vitime [To the history of study of the ancient pottery in the Upper Vitim River valley]. In: Kharinsky AV, editor. Sotsiogenez $v$ Severnoi Azii. Chast 1. Irkutsk: Izdatelstvo Irkutskogo Gosudarstvennogo Tekhnicheskogo Universiteta. p 5963. In Russian.

Vlasov VK, Kulikov OA. 1989. Radiothermoluminescence dating and applications to Pleistocene sediments. Physics and Chemistry of Minerals 16:551-8.

Waters MR, Forman SL, Pierson JM. 1999. Late Quaternary geology and geochronology of Diring Yuriakh, an Early Paleolithic site in central Siberia. Quaternary Research 51(2):195-211.

Zenin VN. 2002. Major stages in the human occupation of the West Siberian Plain during the Paleolithic. Archeology, Ethnology and Anthropology of Eurasia 3(4)[no. 12]:22-44. 